ISSN 2616-7328 (Online), ISSN 2409-904X (Print)

Kitaêznavčì doslìdžennâ, 2021, No. 4, pp. 56-82

DOI: https://doi.org/10.51198/chinesest2021.04.056

UDC 328.18

\title{
POLITICAL, ECONOMIC, SCIENTIFIC, TECHNICAL AND CULTURAL EXCHANGES BETWEEN HUBEI PROVINCE AND THE REGIONS OF UKRAINE IN THE XXI CENTURY
}

\author{
Tian Yuan \\ PhD of Philological Sciences, Associate Professor \\ the Russian language faculty of the Institute of foreign languages of Wuhan University, \\ the Center for Ukrainian studies of Wuhan University, PRC \\ whtt9200@163.com
}

In the XXI century, Hubei Province maintains friendly contacts and exchanges with the regions of Ukraine in the political, economic, scientific, technological and humanitarian spheres. New regular political exchange projects between Hubei Province and Ukrainian regions are announced and documents to contribute to the development of comprehensive relations are signed. In addition, the volume of exported and imported goods from both sides continues to grow. China has also made great strides in attracting Ukrainian specialists in education and technology fields. Since the beginning of the coronavirus pandemic, the Chinese and Ukrainian people have been providing great assistance to each other, as well as expanding cooperation in fields of medicine and healthcare. The exchange between Hubei Province and the regions of Ukraine is becoming multilateral and multifaceted: not only state structures, but also enterprises, universities, institutions and even individual employees have become subjects of their international cooperation.

However, due to the growth of the economy and the rise of the global political status, neither Chinese nor Ukrainian sides considered each other as prior partners for further cooperation, and their relations developed in different political and economic directions. Considering the large-scale cooperation between Ukraine and other Chinese provinces, as well as economic growth and foreign investment increase in the Hubei province, the rapid development of exchanges and cooperation between the "Fish and Rice" region and the "European Granary" is also expected. Chinese Ukrainists and Ukrainian Sinologists can and should help each other to expand and deepen mutual understanding and friendship between Chinese and Ukrainian people.

Keywords: Hubei, Ukraine, exchange, politics, economy, science and technology, humanitarian contacts.

(C) 2021 Tian Yuan; Published by the A. Yu. Krymskyi Institute of Oriental Studies, NAS of Ukraine and the Ukrainian Association of Sinologists on behalf of The Chinese Studies. This is an Open Access article distributed under the terms of the Creative Commons Attribution License (https://creativecommons.org/licenses/by-nc-nd/4.0/). 


\section{ПОЛІТИЧНІ, ЕКОНОМІЧНІ, НАУКОВО-ТЕХНІЧНІ ТА КУЛЬТУРНІ ОБМІНИ МІЖ ПРОВІНЦІЕЮ ХУБЕЙ ТА ОБЛАСТЯМИ УКРАЇНИ У ХХІ СТОЛІТТІ}

\section{Тянь Юань}

У XXI столітті провінція Хубей підтримує дружні контакти та здійснює обміни 3 областями України у політичній, економічній, науково-технічній та гуманітарній сфеpax. 3'явилися нові регулярні проєкти політичного обміну між провінцією Хубей та українськими областями, а також підписано документи, що сприяють розвитку всебічних відносин. Крім того, продовжує зростати обсяг експортованих та імпортованих товарів обох сторін. Китай також досяг великих успіхів у залученні українських фахівців у галузі освіти та технологій. 3 початку пандемії коронавірусу китайський та український народи завжди надавали один одному велику допомогу, а також розширили співпрацю у галузі медицини та охорони здоров'я. Обмін між провінцією Хубей та областями України набуває багатостороннього та багатопланового характеру, а суб'єктами їх міжнародного співробітництва стали не лише державні структури, а й підприємства, виші, установи і навіть окремі співробітники.

Проте через зростання економіки та підвищення світового політичного статусу ні китайська, ні українська сторона не розглядали одна одну як пріоритетний партнер для подальшої співпраці, а їхні відносини розвивалися в різних політичних та економічних напрямах. 3 огляду на масштабну співпрацю України 3 іншими китайськими провінціями, а також економічне зростання та збільшення іноземних інвестицій у пров. Хубей, також очікується і стрімкий розвиток обмінів та співпраці між Краєм риби та рису та Європейським зерносховищем. Китайські українознавці та українські китаєзнавці можуть і повинні надавати один одному допомогу з метою розширення та поглиблення взаєморозуміння та дружби між китайським та українським народами.

Ключові слова: Хубей, Україна, обмін, політика, економіка, наука та техніка, гуманітарні контакти.

\section{ПОЛИТИЧЕСКИЕ, ЭКОНОМИЧЕСКИЕ, НАУЧНО-ТЕХНИЧЕСКИЕ И КУЛЬТУРНЫЕ ОБМЕНЫ МЕЖДУ ПРОВИНЦИЕЙ ХУБЭЙ И ОБЛАСТЯМИ УКРАИНЫ В ХХІ ВЕКЕ}

\section{Тянь Юань}

В XXI веке провинция Хубэй поддерживает дружественные контакты и осуществляет обмены с областями Украины в политической, экономической, научно-технической и гуманитарной сферах. Появились новые регулярные проекты политического обмена между провинцией Хубэй и украинскими областями, а также были подписаны документы, способствующие развитию всесторонних отношений. Кроме того, продолжает расти объем экспортируемых и импортируемых товаров обеих сторон. Китай также добился больших успехов в привлечении украинских специалистов в области образования и технологий. С начала пандемии коронавируса китайский и украинский народы всегда оказывали друг другу большую помощь, а также расширили сотрудничество в области медицины и здравоохранения. Обмен между провинцией Хубэй и областями Украины приобретает многосторонний и многоплановый характер, а субъектами их международного сотрудничества стали не только государственные структуры, но и предприятия, вузы, учреждения и даже отдельные сотрудники. 
Однако из-за роста экономики и повышения мирового политического статуса ни китайская, ни украинская стороны не рассматривали друг друга в качестве приоритетного партнера для дальнейшего сотрудничества, а их отношения развивались в разных политических и экономических направлениях. Учитывая масштабное сотрудничество Украины с другими китайскими провинциями, а также экономический рост и увеличение иностранных инвестиций в пров. Хубэй, также ожидается и стремительное развитие обменов и сотрудничества между Краем рыбы и риса и Европейским зернохранилищем. Китайские украиноведы и украинские китаеведы могут и должны оказывать друг другу помощь с целью расширения и углубления взаимопонимания и дружбы между китайским и украинским народами.

Ключевые слова: Хубэй, Украина, обмен, политика, экономика, наука и техника, гуманитарные контакты.

Отношения между провинцией Хубэй и областями Украины берут свое начало с 1960-х годов. В 60-90-е годы XXI века обе стороны осуществляли обмен и сотрудничество в области политики, экономики и торговли, науки и техники, гуманитарных исследований, образования, культуры, благодаря чему им удалось достигнуть заметных результатов и накопить большой опыт [Тянь... 2020].

В XXI веке провинция Хубэй поддерживает дружественные контакты и осуществляет обмены с областями Украины в политической, экономической, научно-технической и гуманитарной сферах. Появились новые регулярные проекты политического обмена между провинцией Хубэй и украинскими областями, а также были подписаны документы для развития всесторонних отношений. С 2000 по 2021 гг. между провинцией Хубэй и украинскими областями, а также их городами было осуществлено 34 визита на административном уровне. Однако в 2008, 2012, 2014, 2015 и 2016 гг. в связи с событиями политического и экономического характера, происходящими в Китае и Украине, стороны не проводили обмены визитами.

Дальше будет идти речь о событиях, происшедших в период с 2000 по 2021 гг.

В период с 15 ноября по 1 декабря 2000 года председатель НПКСК провинции Хубэй Ли Цюань (李泉) возглавлял делегацию, прибывшую в Запорожье. Во время своего визита он принял участие в праздновании столетия Запорожского государственного технического университета [乌克兰扎波罗热 市 2017].

6 марта 2001 года вице-губернатор Цзя Тяньцзэн (贾天增) встретился с заместителем Министра Украины по вопросам чрезвычайных ситуаций и по делам защиты населения от последствий Чернобыльской катастрофы Александром Скипальским. Ранее Китай предоставлял Украине целебные травы китайской медицины под названием сяньцзи (仙吉饮) для лечения радиационно-индуцированных заболеваний. Так как это лекарство производится в провинции Хубэй, украинская сторона решила провести переговоры о сотрудничестве с некоторыми хубэйскими фармацевтическими заводами [湖北省长... 2001]. В этом же году глава Постоянного комитета ВСНП пров. Хубэй Гуань Гуанфу（关广富） возглавил делегацию в Украину [新武汉史记 2010: 84]. В период с 16 ноября по 2 декабря делегация труппы Хуанмэй пров. Хубэй во главе с директором Чжан Хуажуном (章华荣) посещала Киев, где 
она принимала участие в третьем Фестивале короткометражной драмы [李银 阶2001]. В этом же году 13 сентября торгово-экономическая делегация города Ичан, прибывшая в Киев, подписала договор с Институтом Е.О. Патона о создании Хубэйской сварочной компании Патон-Хован [乌克兰扎波罗热市 2017], благодаря чему удалось открыть новую страницу импорта новейшей сварочной технологии Украины в Хубэй (об этом речь пойдет далее).

16 октября 2002 г. состоялся первый Международный форум развития побратимских отношений с городом Ухань, который открыл новую страницу в истории внешней политики не только города Ухань, но и всего Китая. По словам мэра Уханя Ли Сяньшэня, роль форума состояла в «институционализации и специализации экономического сотрудничества с целью содействия общему процветанию и развитию городов-побратимов». Форум проводится раз в два года и на сегодняшний день представляет платформу для развития сотрудничества между 110 городами мира. В первом форуме участие принимал заместитель председателя КГГА Иван Петрович Данькевич, который вместе с присутствующими подписал Уханьский меморандум о взаимопонимании по вопросам обменов и сотрудничества между дружественными городами мира в новом столетии [新武汉史记2001: 762].

В 2003 году заместитель секретаря провинциального комитета КПК и глава Постоянного комитета ВСНП провинции Хубэй Ян Юнлян（杨永良） во главе экономической делегации посетил Украину. Во время визита был заключен Договор о дружеском сотрудничестве между провинцией Хубэй и Киевской областью. Также стороны выразили 18 различных намерений, в частности, намерение компании Уфэн открыть чайную фабрику в Киеве. Компания Тяньфа выразила намерение выращивать рапс, обрабатывать подсолнечное масло и производить стиральный порошок в Украине, а компания Ханьця была намерена открыть дочернюю фирму в Киеве и производить металлопластиковые окна в Броварах. Кроме того, Хубэйский исследовательский институт механизмов и электроники планировал заимствовать у Института металлофизики НАН Украины технологию производства матриц, а Хубэйская компания материалов Хуагуан была намерена развивать сотрудничество с Институтом монокристаллов НАН Украины. В этом же году Украину также поочередно посещали хубэйские комиссии по вопросам коммуникации, водного промысла, картографирования, политики и законодательства. Хубэйская Ассоциация дружбы с зарубежными странами и украинское Общество украинско-китайской дружбы подписали Меморандум об установлении дружеских связей [新 武汉史记2001: 59].

30 июня 2003 г. в Пекине состоялась встреча между губернатором провинции Хубэй Ло Цинцюанем (罗清泉) и послом Украины в Китае Михаилом Резником. В результате стороны достигли соглашения по поводу строительства украинского высокотехнологичного сельскохозяйственного парка в провинции Хубэй [乌克兰将在... 2003].

24 октября 2004 года во время телефонного разговора с правительством провинции Хубэй посол Китая в Украине Яо Пэйшэн（姚培生） сообщил о том, что украинская сторона надеется на дальнейшее укрепление всесторонних отношений сотрудничества с Хубэем, в частности с городом Ичан [乌克兰 扎波罗热州... 2004]. 
В период с 28 мая по 29 июня 2004 г. вице-мэр Уханя Чжан Сюэман (张 学忙) во главе делегации посетил Киев. Во время своего визита он принял участие в мероприятиях, посвященных празднованию Дня Киева [武汉市代表 团访问基辅波尔多 2004].

С 30 октября по 1 ноября 2005 г. хубэйская научно-техническая делегация во главе с заместителем председателя НПКСК провинции Хубэй Ху Юнцзи

（胡永继） посетила Киев. Во время визита представители делегации провели переговоры с Институтом Е.О. Патона НАН Украины и другими профильными ведомствами. Также обе стороны обсудили новые направления развития будущего сотрудничества, в результате чего они пришли к общему мнению по обсуждаемым вопросам [省科技... 2005].

С 20 по 24 июля 2006 г. китайская делегация во главе с вице-губернатором провинции Хубэй Лю Юфанем（刘友凡） посетила Украину. Стороны подписали рамочное соглашение о сотрудничестве в области сельского хозяйства [乌克兰将 从中国进口1000辆客车 2006]. С 7 по 10 сентября того же года замруководителя СНП пров. Хубэй Ця Тяньцзин (贾天增) возглавил делегацию, посещавшую Одесскую область. Обе стороны подписали Протокол о дружбе и сотрудничестве, а также Письмо о намерениях сотрудничества [湖北省友好代表团结束... 2006].

В 2006 г. Китай и Украина начали сотрудничать в области машиностроения. 30 июня в Ухане состоялась церемония подписания Договора между компанией Дунфэн и корпорацией «Богдан» о строительстве нового завода по производству грузовых автомобилей. Строительство завода планировалось в Черкассах, а общая сумма инвестиций составляла более 35 млн. долларов. Стороны планировали выпускать до 13 тысяч грузовых автомобилей грузоподъемностью от 2 до 10 тонн [“东风汽车”乌克兰07年竣工... 2006]. В этом же году компания Дунфэн получила государственную лицензию на производство 5 моделей автомобилей и право реализовать автобусы на украинском рынке общественного транспорта. 21 июля между компанией Дунфэн и компанией Китбренд был подписан договор о продаже 1000 автобусов, которые были произведены в соответствии с условиями украинского климата и состоянием дорог [ 东风汽车: 机构重仓... 2006]. В этом же году компания Дунфэн также экспортировала в Украину 1842 легких грузовиков. По словам коммерческого представителя посольства КНР в Украине Гао Сиюня, машиностроение является ключевой отраслью китайско-украинского торгово-экономического сотрудничества. Объем торговли в этой сфере должен был достигнуть 200 млн. долларов [乌克 兰博格丹集团... 2013]. Однако, к сожалению, проект нового завода компании Дунфэн и компании Богдан так и не был реализован.

Провинция Хубэй также вошла на украинский рынок подержанных автомобилей. 11 мая 2021 года на условиях FOB компания Дунфэн отправила в Украину 8 подержанных электрических автомобилей на новых источниках энергии. Это была первая доставка заказа, стоимость которой превысила 100 тысяч долларов [首班武汉直达乌克兰... 2020]. Машиностроение можно считать одной из ключевых промышленных отраслей, которая сможет открыть большие возможности для экономического развития Украины путем экспорта товаров, техники и привлечения инвестиций [湖北将... 2021].

В августе-сентябре 2007 г. во главе с губернатором провинции Хубэй Луо Цинцюанем хубэйская правительственная делегация пребывала в Украине с 
дружественным визитом, целью которого было расширение сфер сотрудничества с Киевской областью [湖北年鉴2008, 273]. Хубэйская компания Хоуван и Институт проблем материаловедения НАН Украины подписали Соглашение о внедрении технологий и расширении сфер сотрудничества. Хубэйская компания комплектного оборудования и Национальный олимпийский комитет Украины заключили Намерение о строительстве спортивных сооружений, автошоссе и гостиниц. Правительство провинции Хубэй подчеркивало необходимость углубления сотрудничества между хубэйскими и украинскими научными учреждениями путем оказания технических услуг, привлечения акционеров и задействования интеллектуальных ресурсов [关于... 2007].

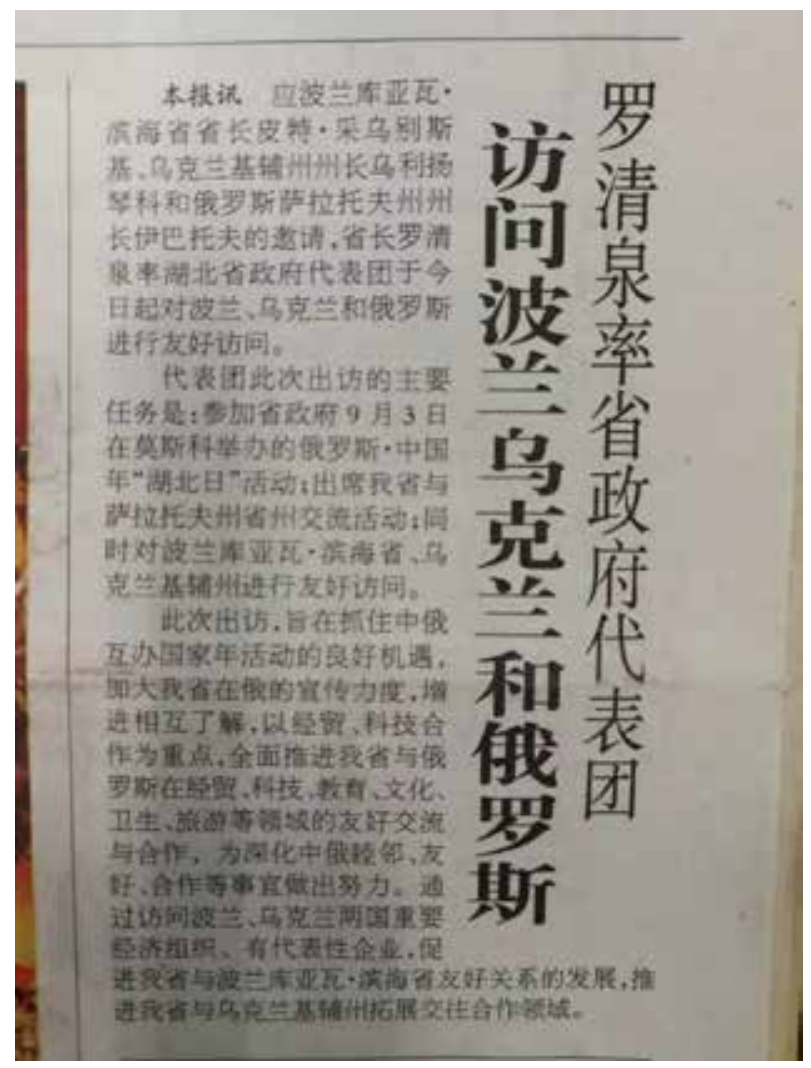

\section{Фото 1. Хубэйская правительственная делегация во главе с губернатором провинции Хубэй Луо Цинцюанем прибыла с дружественным визитом в Польшу, Украину и Россию. Хубэй жибао от 24 августа 2007 г.}

В июне 2008 г. Хубэйская компания Чанъянхунсинь прибыла в Украину для участия в переговорах с запорожской компанией УНИКОН. Стороны заключили Договор о дальнейшем исследовании марганцевой руды на сумму 20 млн. долларов [湖北长阳宏信... 2008].

В ноябре 2009 г. мэр Киева отправил письмо мэру Уханя Жуань Чэнфа с просьбой оказания помощи в борьбе с вирусом Н1N1. Мэр Уханя сразу же направил Уханьскому Обществу Красного Креста приказ о предоставлении Киеву финансовой помощи в размере 500 тысяч юаней [武汉携手... 2013]. 
В сентябре 2010 г. замруководителя Постоянного комитета ВСНП пров. Хубэй Цзян Даго (蒋大国) возглавил дружественную делегацию, прибывшую в Украину. Делегация посетила Киевский городской совет, областную государственную администрацию, а также культурно-художественную школу Киевской области. Стороны пришли к общему выводу о необходимости установления долгосрочного и эффективного сотрудничества, регулярного обмена визитами, а также обмена студентами [湖北省友好代表团近 日... 2010]. В этом же году между Хубэйской компанией Ляньфэн и Киевской областью был подписан Договор о сотрудничестве в области выращивания овощей на территории общей площадью 30 га, а также об открытии фабрики для переработки сельскохозяйственных продуктов [湖北省农辱... 2011]. В 2011 году технические сотрудники компании Ляньфэн успешно завершили экспериментальную посадку пекинской капусты, огурцов, перцев, помидоров, вигны китайской в китайско-украинском показательном сельскохозяйственном парке [蔡志文，徐章2011].

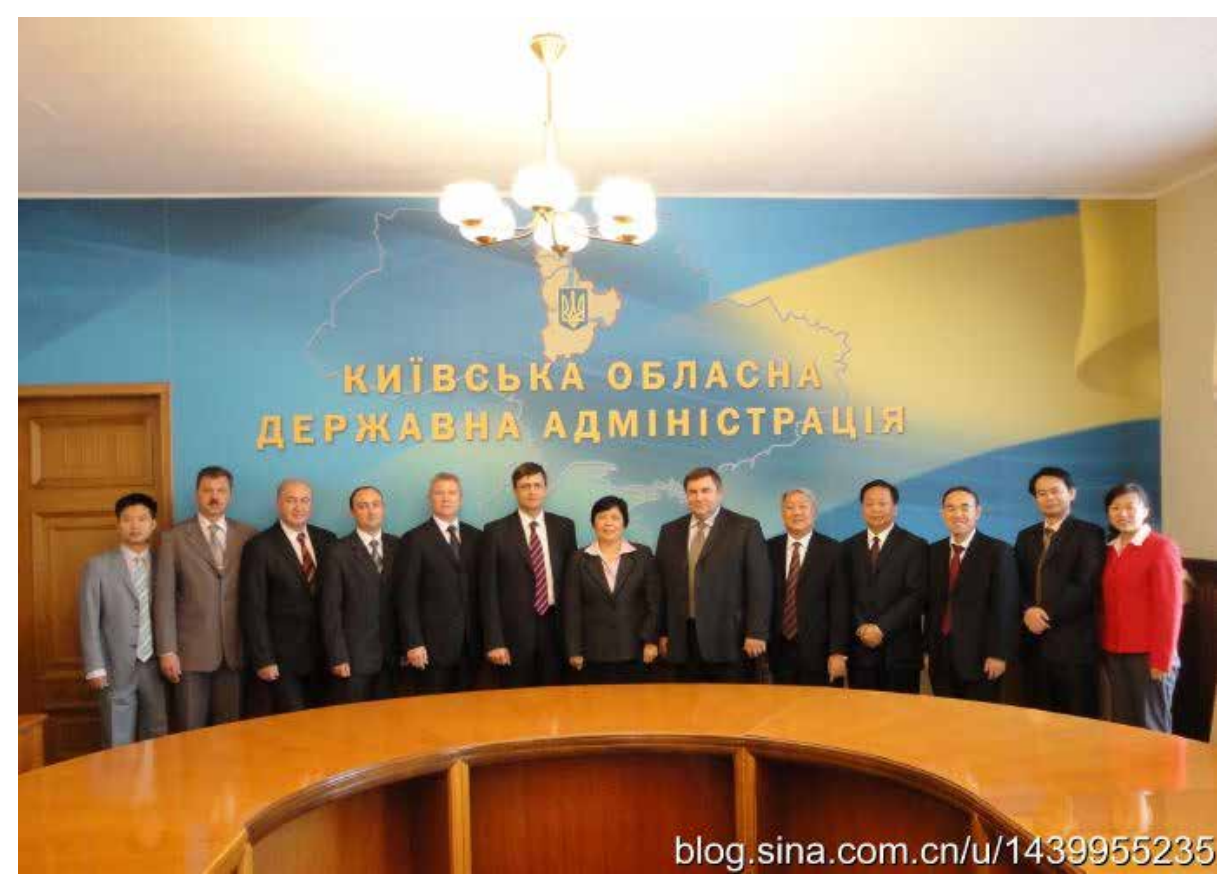

Фото 2. Хубэйская дружественная делегация в Украине в ноябре 2010 г.

29 марта 2011 года состоялась встреча между заместителем губернатора и членом постоянного комитета провинциального комитета КПК Чжан Дайли (张岱梨) и первым заместителем главы Киевской облгосадминистрации Ярославом Москаленко, прибывшим вместе с делегацией в провинцию Хубэй. Во время визита киевская делегация учувствовала в переговорах с такими профильными структурами, как Олимпийский спортивный центр и Чжуннаньская больница [乌克兰基辅州第一... 2011]. 10 сентября того же года Чжан Дайли во главе хубэйской правительственной делегации посетил Украину. Во время своего визита он встретился с Анатолием Присяжнюком 
и председателем Киевоблсовета Александром Качным, а также подписал протокол, посетил спортивные центры, школы и больницы [张岱梨... 2011]. 17 ноября 2011 года в Хубэе состоялась встреча между губернатором провинции Хубэй Ван Гошэном（王国生） и главой Киевской облгосадминистрации Анатолием Присяжнюком, во время которой обе стороны обсудили необходимость укрепления торгово-экономического сотрудничества. Гости посетили больницу Тунци, компанию Дунфэн, ферму Уху и другие организации [乌克兰 基辅州州长... 2011].

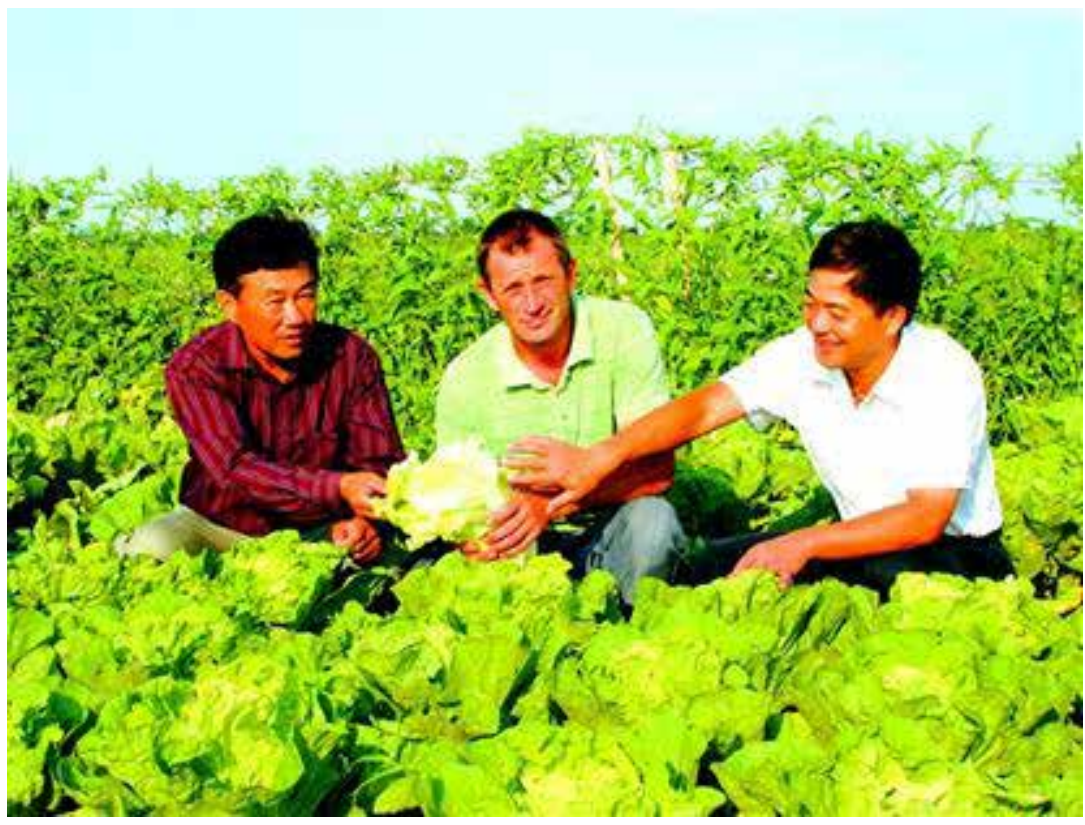

Фото 3. В 2011 году технические сотрудники компании Ляньфэн успешно завершили экспериментальную посадку овощей в показательном китайско-украинском сельскохозяйственном парке

10 сентября 2012 года украинский профессор Анатолий Иванович Троцан был награжден китайской правительственной «Премией дружбы». Анатолий Троцан хорошо известен как начинающий специалист в области внепечного рафинирования черных металлов и микролегирования стали. В 1999 году он был удостоен Государственной премии Украины в области науки и техники. В 2002 году он получил приглашение от Компании сварочных материалов Хоуван из города Сяньтао на занятие должности старшего технического советника. Профессор руководил исследованием и разработкой технологий для микролегированных композитных порошковых проволок и получил Китайский государственный патент на изобретения. Кроме того, Анатолий Троцан помог компании Хоуван получить несколько патентов на изобретение микролегированных композитных порошковых проволок, что помогло Китаю заполнить его технологический пробел. В октябре 2004 г. была запущена линия производства металлургических композитных порошковых проволок, в которую было инвестировано 9 млн. юаней. В конце этого же года объем продаж продукта достиг 10,82 млн. юаней [湖北猴王... 2004]. В 2005 году 
проволоки компании Хоуван стали применять в производстве оборонной стали [湖北省志2003, 84]. В 2008 году компания производила более 10 сортов проволок, объем продажи которых превысил 80 млн. юаней. Благодаря этому размер налога с прибыли, который компания вносила в государство, составлял 1,5 млн. юаней [湖北省志2003, 272]. В этом же году по указу Президента Украины Виктора Ющенка Анатолию Троцану было присвоено почетное звание «Заслуженный изобретатель Украины». 30 сентября 2010 года Анатолий Иванович Троцан стал лауреатом Хубэйской правительственной премии Бяньчжун «Выдающийся иностранный специалист провинции Хубэй 2010 года» [贡献智慧... 2010].

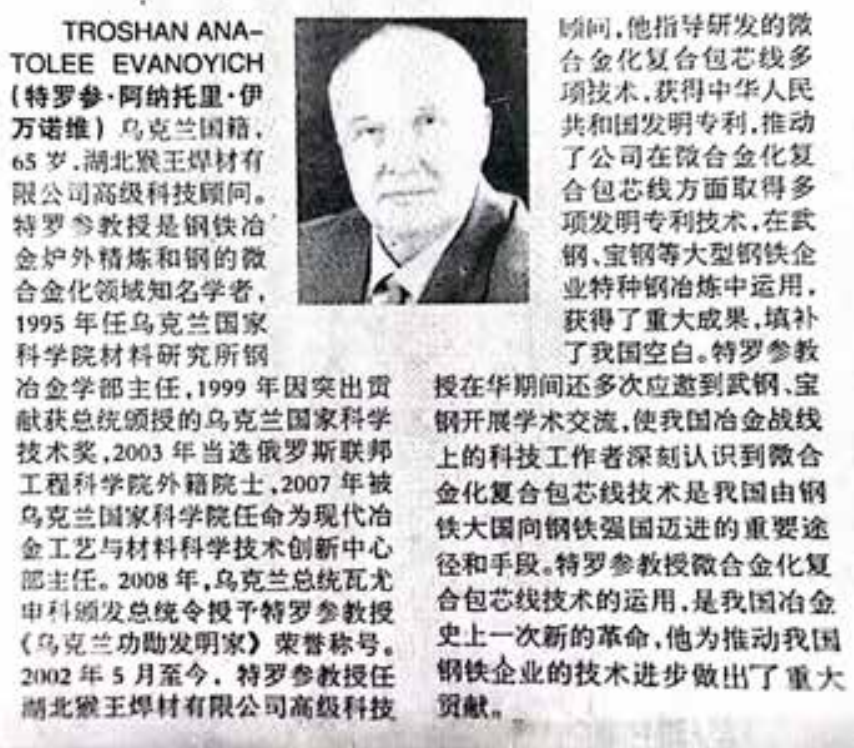

\section{Фото 4. Анатолий Иванович Троцан удостоен премии «Бяньчжун» провинции Хубэй в 2010 г. Хубэй жибао от 29 сентября 2010 г.}

28 мая 2018 года Анатолий Троцан стал заслуженным профессором Уханьского научно-технического университета. Используя свои преимущества в изучении металлургии, университет решил создать комплексное исследовательское учреждение вместе с профессором и компанией Хоуван для развития металлургической промышленности Китая. С целью объединения украинских и китайских интеллектуальных сил, помимо профессора Троцана, университет также пригласил таких академиков НАН Украины, как Олег Исаев и Александр Глесс, а также специалистов Хуачжунского политехнического университета. В результате на основе работы производственной инновационной федерации и нового исследовательского учреждения была разработана самая прочная в мире мостовая сталь 2000МР и устойчивая к коррозии сталь, которую можно использовать в морской воде [湖北端出... 2021]. Опыт привлечения украинских специалистов, который был продемонстрирован Уханьским научно-техническим университетом, а также Уханьским текстильным университетом, стоит перенять и остальным вузам Хубэя. Для успешного сотрудничества 
иностранным академикам нужно предоставить не только выгодные условия работы и жизни, но и хороших переводчиков. К примеру, компания Хоуван пригласила профессора Ли Чжиюаня (李志远) из Хуачжунского политехнического университета, который в 50-ые годы учился в СССР, в качестве ведущего специалиста с китайской стороны. В докладе о практической осуществляемости проекта комплексной сварочной проволоки 2003 г. указано: «Специалист с китайской стороны имеет опыт учебы в Советском Союзе, обладает глубокими специализированными знаниями и хорошо владеет русским языком, что обеспечивает полноценное общение с украинскими специалистами и полноценное принятие технологии сварочной проволоки» [湖北猴王... 2004]. С другой стороны, украинские специалисты получают возможность практиковать и развивать свои теории, и, соответственно, способствуют подготовке нового поколения ученых в Украине.

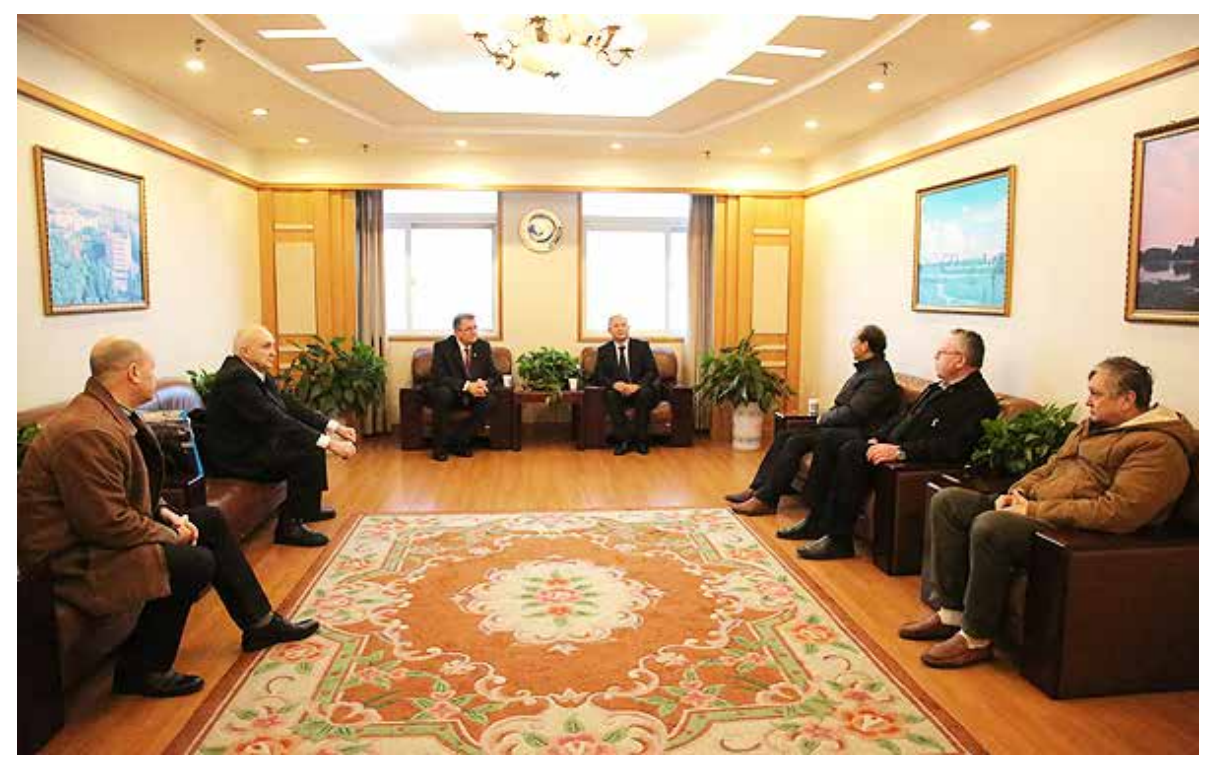

Фото 5. Украинские специалисты на встрече ректора Уханьского технического университета Ни Хунвэя с заместителем ректора Национальной металлургической академии Украины Юрием Сергеевичем Пройдаком 18 декабря 2018 г.

В 2013 году вице-губернатор провинции Хубэй Чжан Тун (张通) во главе хубэйской экономической дружественной делегации посетил Киевскую область. Во время визита он встретился с главой КГГА Анатолием Присяжнюком и заместителем председателя Днепропетровского областного совета Владимиром Перегудовым, а также посетил Государственную продовольственнозерновую корпорацию Украины и Укргазбанк [张通... 2013].

21 ноября 2013 года глава Департамента экономики и инвестиций КГГА Николай Поворозник принял участие в Уханьском международном саммите дружбы, а также посетил Район экономической разработки и Район разработки высоких и новых технологий озера Дунху. Он также выразил пожелание развивать сотрудничество с провинцией Хубэй в области промышленности, 
высокотехнологического и экологического производства [2013武汉国际交 流... 2013].

С 2014 по 2016 гг. между администрациями провинции Хубэй и областями Украины не было официальных визитов. Тем не менее общение между народами продолжалось и развивалось благодаря научно-образовательному сотрудничеству.

В 2015 году украинский китаевед Ирина Илийчук окончила докторантуру в Уханьском университете. Прекрасно владея китайским языком, Ирина проводила международные фестивали Уханьского университета, была ведущей телепрограммы «Занимательный китайский язык» CCTV-4 и приобрела богатый опыт практики китайской речи. На выпускной церемонии Ирина выступала с речью в качестве представителя лучших студентов. Копия ее диплома доктора наук была добавлена в коллекцию Архива УУ. После окончания докторантуры она начала преподавать китайский язык в Прикарпатском национальном университете им. Василия Стефаника и Львовском национальном университете им. Ивана Франка. Ирина и ее семья занимаются активным продвижением китайской культуры [Стражник 2021]. В 2018 году, представляя свой университет, Ирина приняла участие в Первой Шанхайской международной выставке импортных товаров. В Шанхае она также была переводчиком бывшего президента Украины В.А. Ющенко. В 2019 году она дала интервью журналистам хубэйской газеты «Чанцянь жибао», а также призывала побольше рассказывать украинским студентам об Ухане. В апреле 2021 года Ирина была членом жюри на Первом всеукраинском конкурсе переводчиков китайского языка, организованном Институтом востоковедения им. А.Ю. Крымского НАН Украины, Украинской ассоциацией китаеведов и Уханьским университетом.

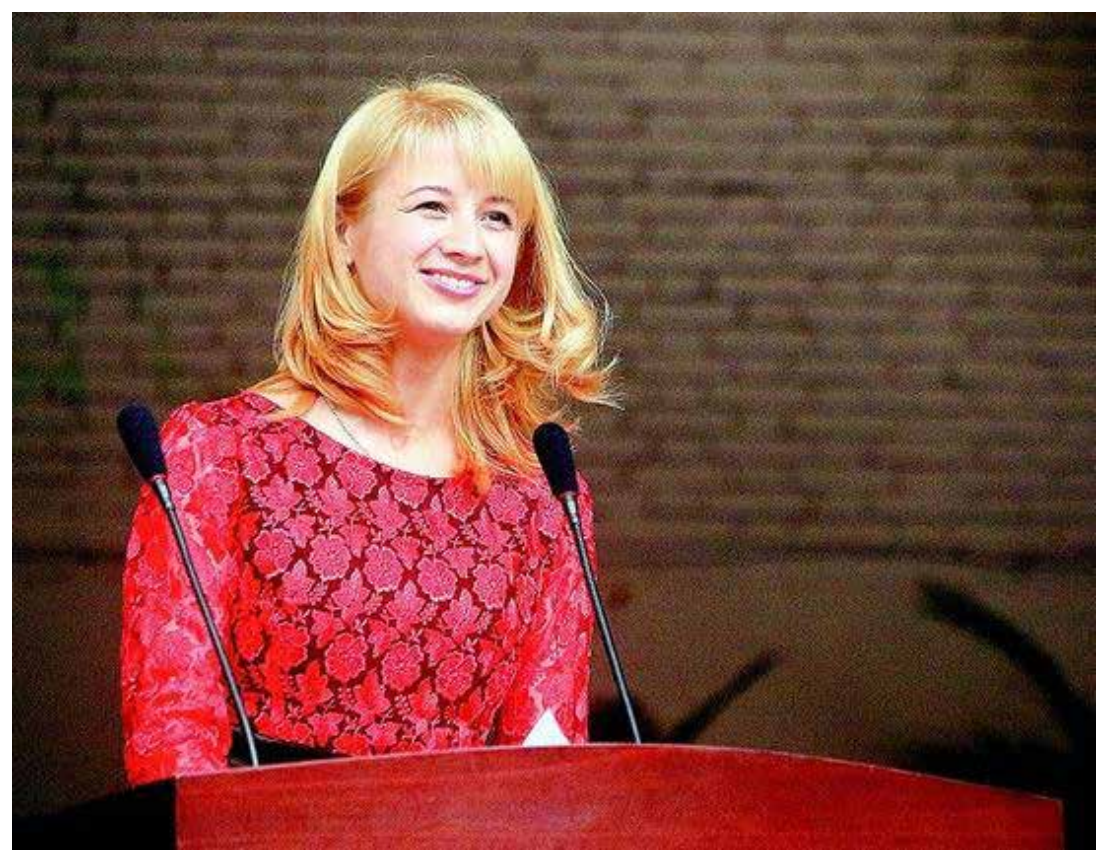

Фото 6. Ирина Илийчук выступила с речью на выпускной церемонии Уханьского университета 
Также следует отметить роль выпускницы факультета русского языка Уханьского Университета Дун Сюэсун (董雪松) в преподавании китайского языка в Киевском национальном лингвистическом университете. Дун Сюэсун окончила университет в 1994 году, а в 2008 году начала работать в КНЛУ преподавателем китайского языка. В 2013 году она устроилась на работу в Институт Конфуция КНЛУ. В своей аудитории она воспитала лауреатов конкурса «Китайский мост», которые позже стали отличными дипломатами, переводчиками и преподавателями.

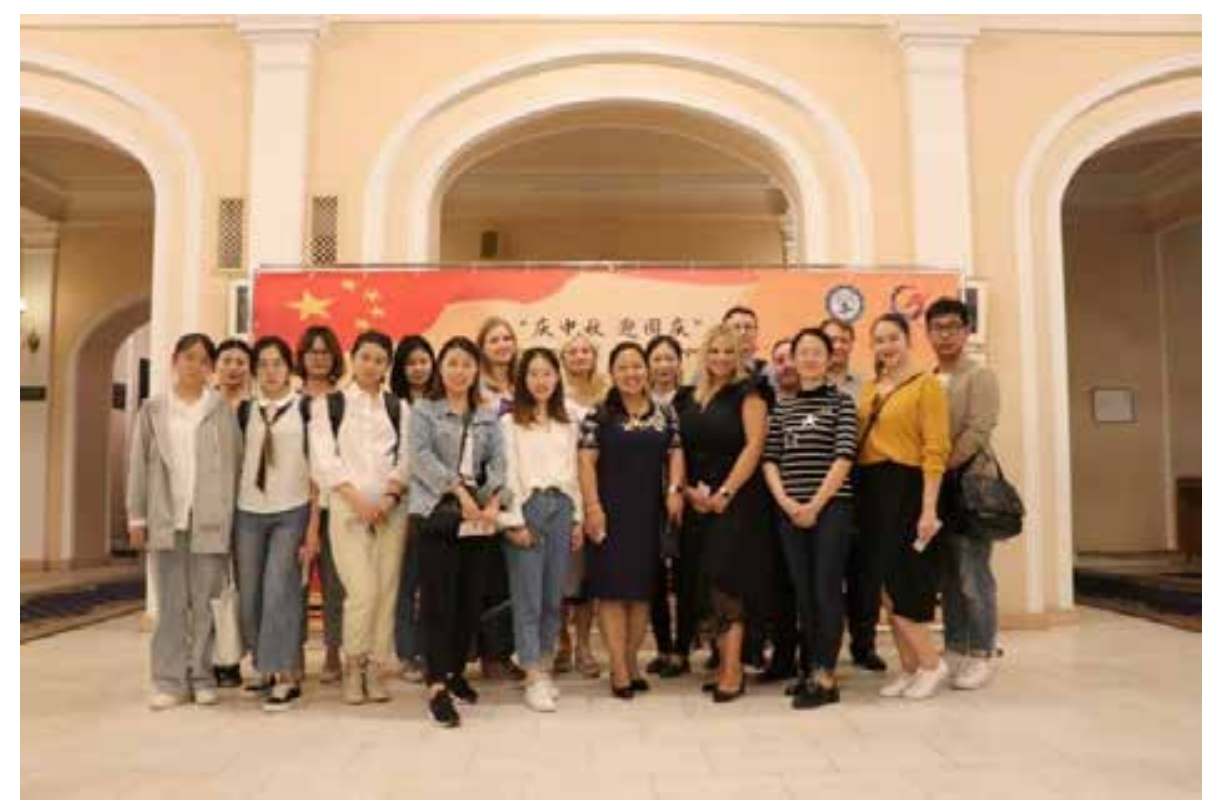

Фото 7. Выпускница факультета русского языка Уханьского университета Ду Сюэсун с преподавателями-волонтерами китайского языка в Институте Конфуция Киевского национального лингвистического университета

С 28 по 29 августа 2016 года бывший советник по культурным вопросам Посольства Украины в КНР, советник ректора по внешним связям Национальной академии изобразительного искусства и архитектуры В.В. Величко принимал участие в Форуме развития провинции Хубэй в рамках инициативы «Один пояс, один путь» в городах Уфэн (五峰) и Ичан [乌克兰教授... 2016]. В период с 24 по 27 декабря 2016 года председатель Украинской ассоциации китайских мигрантов Ли Сян (李相) и президент Международной и Всеукраинской федераций «Фри-файт» Андрей Старовойт с делегацией посещал город Шиянь (十堰) [乌克兰华侨... 2016].

С 2017 года между Китаем и Украиной были восстановлены политические отношения на административном уровне, что способствовало развитию торгово-экономического и научно-образовательного сотрудничества.

В период с 5 по 7 июня 2017 года украинская делегация во главе с мэром Белой Церкви Геннадием Диким посещала город Цзинчжоу. Целью ее визита было способствование академическому сотрудничеству между Университетом Янцзы 
и Национальным аграрным университетом Украины, а также сотрудничеству в сферах сельского хозяйства, медицины и инфраструктуры [荆州市... 2017].

В июне 2017 года китайская делегация во главе с вице-мэром города Ичан Чжоу Чжэнъином (周正英) посетила Запорожье, где вместе с мэром Запорожья Владимиром Буряком подписала «План сотрудничества с городом Ичан на период 2017-2019 гг.» [乌克兰扎波罗热市 2017].

19 сентября 2017 года профессор Чэнь Хуэ (陈辉), а также другие преподаватели Института энергетики и энергетической инженерии Уханьского технического и инженерного университета приняли участие в 13-ой международной конференции «Судовые двигатели», которая проходила в Одесском национальном морском университете [陈辉... 2017].

15 ноября 2017 года мэр Житомира Сергей Сухомлин посетил Уханьский Международный форум городов-побратимов, во время которого состоялась 3-я Конференция по вопросам привлечения инвестиций для крупнейших мировых компаний, которые входят в рейтинг Fortune Global 500, и всемирно известных иностранных компаний. Генеральный директор 11-ого бюро Китайской железнодорожной корпорации Чан Шухай (张树海) вместе с Сухомлиным подписал протокол о сотрудничестве, по которому Одиннадцатое бюро должно было предоставлять комплексные услуги для строительства инфраструктуры Житомира. После подписания соглашения Житомир стал 106-ым городом-побратимом Уханя [友城... 2017].

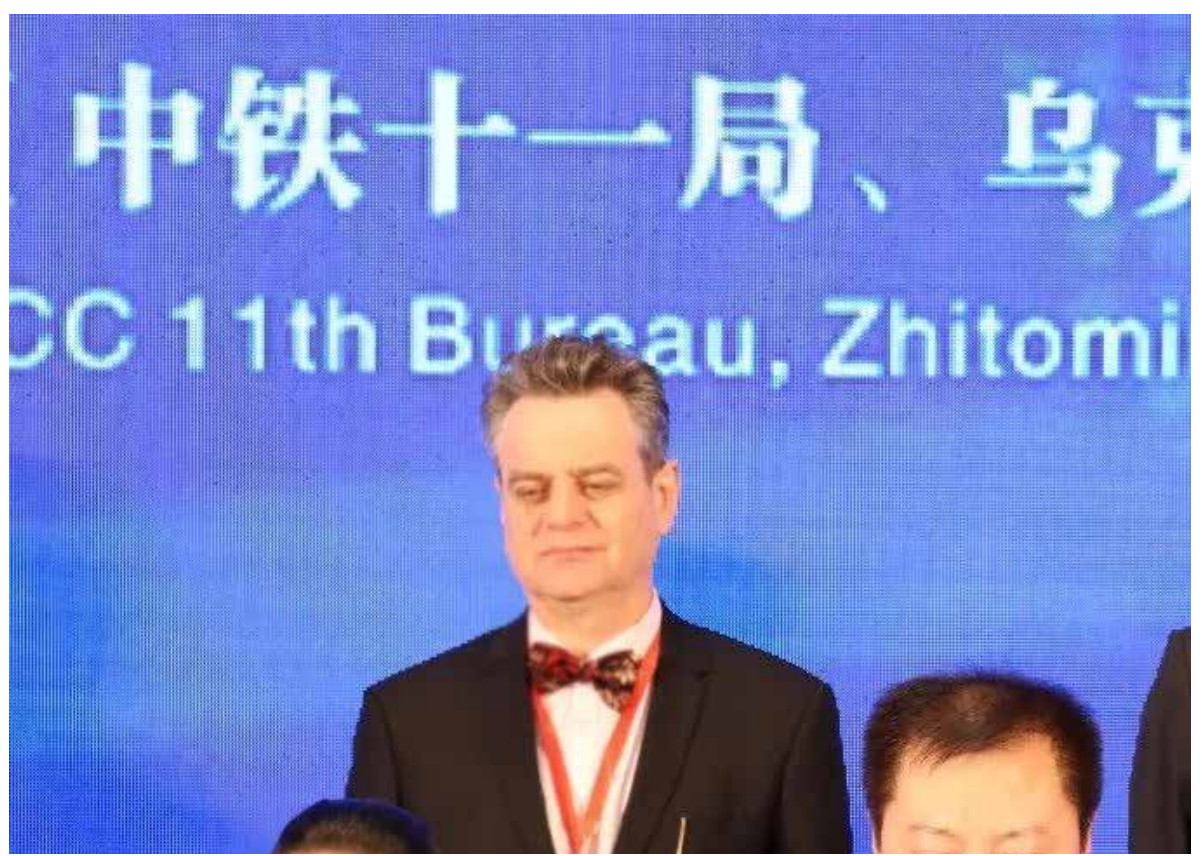

Фото 8. Генеральный директор 11-ого бюро Китайской железнодорожной корпорации Чан Шухай и мэр Житомира Сергей Сухомлин подписали протокол о строительстве инфраструктуры в Житомире

31 октября 2017 года украинские ученые приняли участие в Международном форуме космической лазерной техники и промышленности, который 
состоялся в Районе разработки высоких и новых технологий озера Дунху города Ухань [2017光谷... 2017]. В этом же году украинская делегация из Таврического национального университета имени В.И. Вернадского посетила Хубэйский медико-фармацевтический институт [乌克兰塔夫利达... 2017].

С 21 по 24 ноября 2017 года профессора Хуачжунского политехнического университета Чень Ган (陈刚), Чжао Шихун （赵世红）и Ло Цун（罗聪）принимали участие в Китайской выставке технологий и инноваций, которая проводилась в Украине в честь 25-й годовщины установления дипломатических отношений между Китаем и Украиной. Их технологии сжигания угля заинтересовали представителей Научно-исследовательского института газа, Киевского национального университета и Львовского политехнического университета [我院... 2017].

В мае 2018 года по приглашению мэра Запорожья китайская делегация во главе с заместителем декана Профессионально-технического института Санься Ваном Хуали（王华利） посетила Международную научную конференцию, проходившую в Запорожье [乌克兰扎波罗热市... 2017].

В июне 2018 года посол Украины в Китае Олег Демин возглавил делегацию, посещавшую провинцию Хубэй, а также способствовал участию украинской стороны в сборе экспонатов для будущего первого в Китае Музея советских летчиков-добровольцев в Парке освобождения. Посол посетил Центр изучения Украины при Уханьском университете [乌克兰驻华大使焦明... 2018] и Хубэйский комитет содействия развитию международной торговли, а также ознакомил председателя общества Чжан Сяомэй с преимуществами географического положения Украины, а также ее преимуществами в области сельского хозяйства и инфраструктуры. Посол выразил желание углублять сотрудничество с обществом в сфере высоких технологий, экологического производства и оптико-волоконных связей [章笑梅... 2018].

14 сентября 2018 года в Киеве прошел Семинар по вопросам инвестиций и торговли провинции Хубэй с Украиной, в котором участвовало 50 хубэйских и 150 украинских предприятий [2018中国湖北-乌克兰贸易... 2018]. Были подписаны заявления о намерениях сотрудничества в области сельского хозяйства, экологии, производства автомобильных запчастей, обработки древесины, производства оборудования, развития инфраструктуры, производства пчелиного воска [架设... 2019]. Гости также посетили деревообрабатывающий завод, инвестируемый провинцией Хубэй [2018中国湖北-乌克兰经贸... 2018].

В октябре 2018 года глава Александровского района Запорожья Валерий Мостовой вместе с делегацией прибыл в город Ичан, где посетил Плотину Санься, Выставочный зал проектирования Ичана, Творческий центр Цюсо, научно-технические предприятия Чанци, Синдинь, а также фабрику музыкальных инструментов Циньбао. В результате был подписан Протокол о сотрудничестве между Александровским и Заводским районами Запорожья и Ичанской зоной свободной торговли [乌克兰扎波罗热市 2017].

В ноябре 2018 года заместитель начальника Отдела международных связей КГГА Оксана Матковская приняла участие в Уханьской международной конференции городов-побратимов. Во время конференции она сообщила о том, что недавно узнала о визите Уханьской инжиниринговой компании в Киев, во время которого обсуждались проекты строительства киевского метрополитена [国际友城... 2018]. 


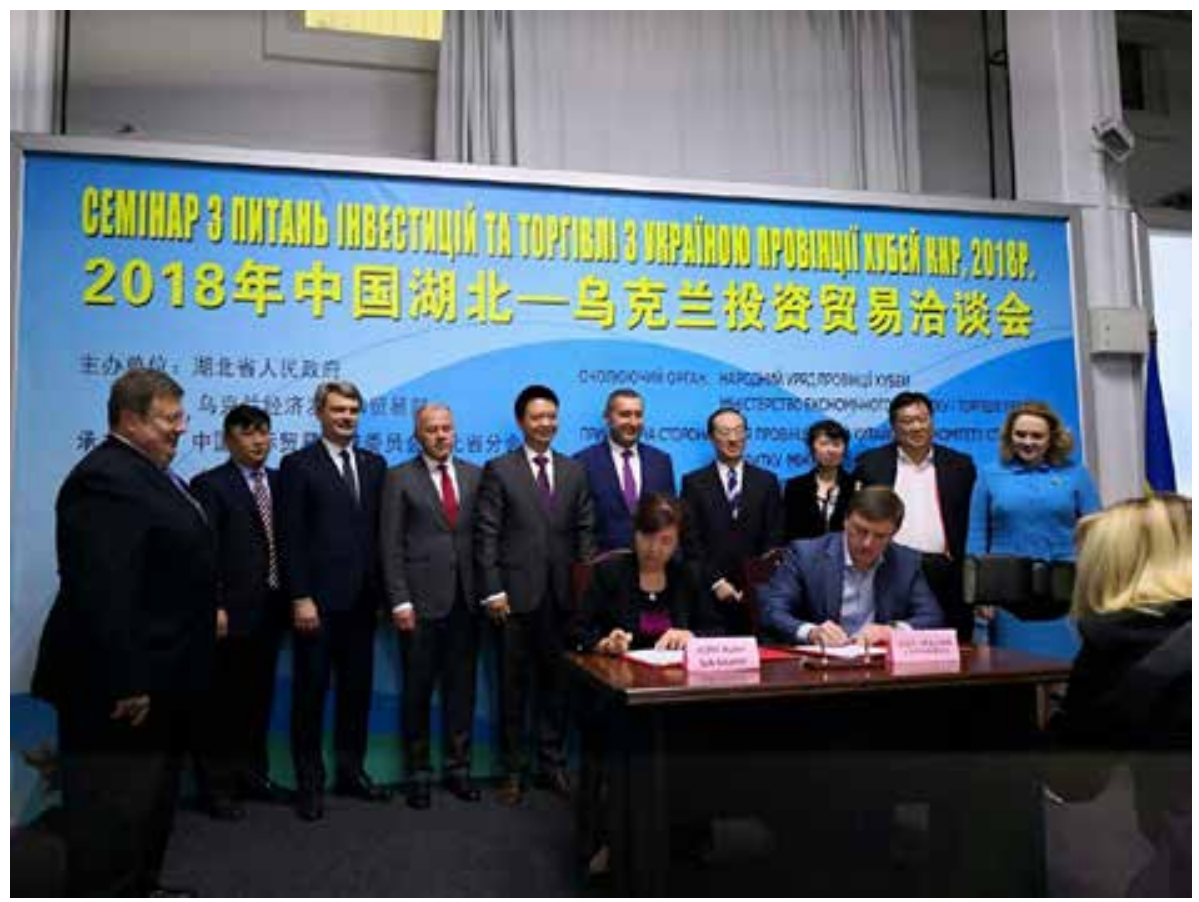

Фото 9. Семинар по вопросам инвестиций и торговли провинции Хубэй с Украиной 14 сентября 2018 г.

5 мая 2019 года состоялась Презентация проекта международной закупки ичанского чая. В этой презентации приняли участие дипломаты и покупатели из Марокко, Кореи, России, Армении и других стран мира, в результате чего было подписано несколько договоров на покупку до 9 тысяч тонн чая общей суммой 110 млн. долларов. Среди этих договоров также был договор о закупке чая, подписанный Хубэйской компанией экологического сельского хозяйства Чэ Си и компанией Жива [2019茶叶... 2019].

В июле 2019 года представители киевской делегации приняли участие в мероприятии, посвященном церемонии открытия 7-ых Всемирных военных игр, которые проводились для жителей городов-побратимов, посетивших Ухань [武汉夜景... 2019]

24 августа 2019 года преподаватели Чжан И (张艺) и Хуан Хоу （黄堠） выступили на концерте «Я и моя родина» в Харьковской национальной библиотеке [湖北高校... 2019].

С 15 по 17 октября 2019 года доценты Запорожского медицинского университета Ольга Паголчук и Тарас Иваненко посетили Хубэйский медико-фармацевтический институт в городе Шиянь. В 2017 году стороны подписали соглашение, в результате чего началось их взаимодействие в области высшего медицинского образования, проведения научных исследований и обмена студентами и преподавателями [乌克兰扎波罗热国立医科... 2019].

В октябре 2019 года представители Департамента культуры и туризма администрации города Ичан выступили на мероприятии, посвященном празднованию Дня города Запорожья [乌克兰扎波罗热市 2017]. 
18 февраля 2020 года Хубэйская компания по экспорту и импорту зерна и масла при Хубэйской инвестиционной корпорации Чанцзян подписала договор об импорте 5 тыс. тонн подсолнечного жмыха из Украины [保畜离... 2020].

Еще одним важным событием в отношениях между Хубэем и Киевом стало прибытие первого китайско-европейского контейнерного поезда «УханьКиев» в Украину 6 июля 2020 года, который встречали представители Китая и Украины на станции Киев-Лиски [直达... 2020]. По этому маршруту в Украину доставлялось сырье для химической промышленности (английская соль), сельскохозяйственная техника (дождевальные машины), а также алюминиевые рамы, шприцы, сумки и т.д. На обратном пути в Ухань из Украины было доставлено молоко, подсолнечное масло, вино, пиво, хлеб и сыр [首班... 2020].

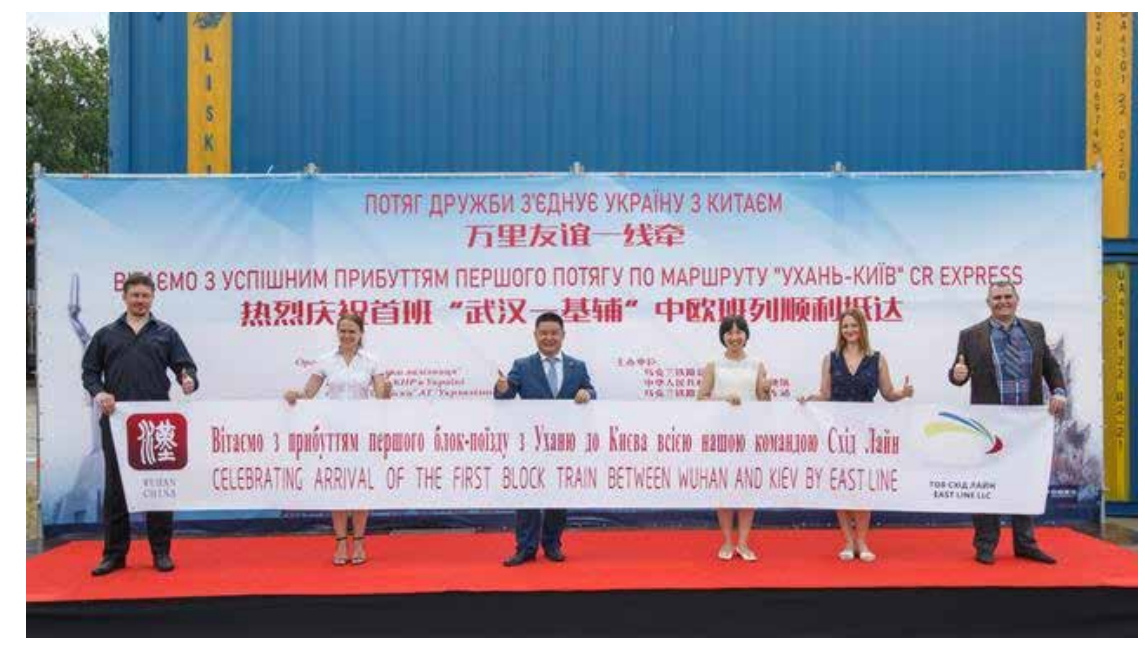

Фото 10. 6 июля 2020 года в Украину прибыл первый китайско-европейский контейнерный поезд «Ухань-Киев»

В 2020 году украинские мигранты в провинции Хубэй неоднократно выражали благодарность городской администрации и хубэйскому населению за оказанную им помощь во время пандемии. Например, на сайте Ванъи была опубликована информация о том, как Сянфанский госслужащий Чжоу Фань

(周凡) помогал украинскому авиационному специалисту Павлу Николаеву и его семье с продуктами и бытовыми товарами во время карантина [乌克兰 友人... 2020].

В ноябре 2020 года посол Украины Сергей Камышев посетил Хубэйскую администрацию, Комитет содействия развитию международной торговли провинции и Центр изучения Украины при Уханьском университете [乌克兰驻华 大使谢尔盖·卡梅舍夫一行...2020］［乌克兰驻华大使谢尔盖·卡梅舍夫来校... 2020].

В 2021 году Уханьский университет подписал договор с Институтом востоковедения им. А.Ю. Крымского НАН Украины и начал активное китайскоукраинское научно-образовательное сотрудничество. В апреле этого же года состоялся Первый всеукраинский конкурс переводчиков китайского языка, победитель которого получил возможность годового обучения в Уханьском 
университете на льготных условиях [乌克兰选手... 2020]. В ноябре 2021 года в Уханьском университете состоялся первый международный симпозиум «Перспективы и пути китайско-украинского научно-технического и образовательного сотрудничества в постпандемический период», в котором приняли участие более 20 китайских и украинских вузов и учреждений. Во время симпозиума обсуждались актуальные вопросы, касающиеся способствования обменов и взаимодействия между китайскими украиноведами и украинскими китаеведами [外语学院俄语系... 2021].

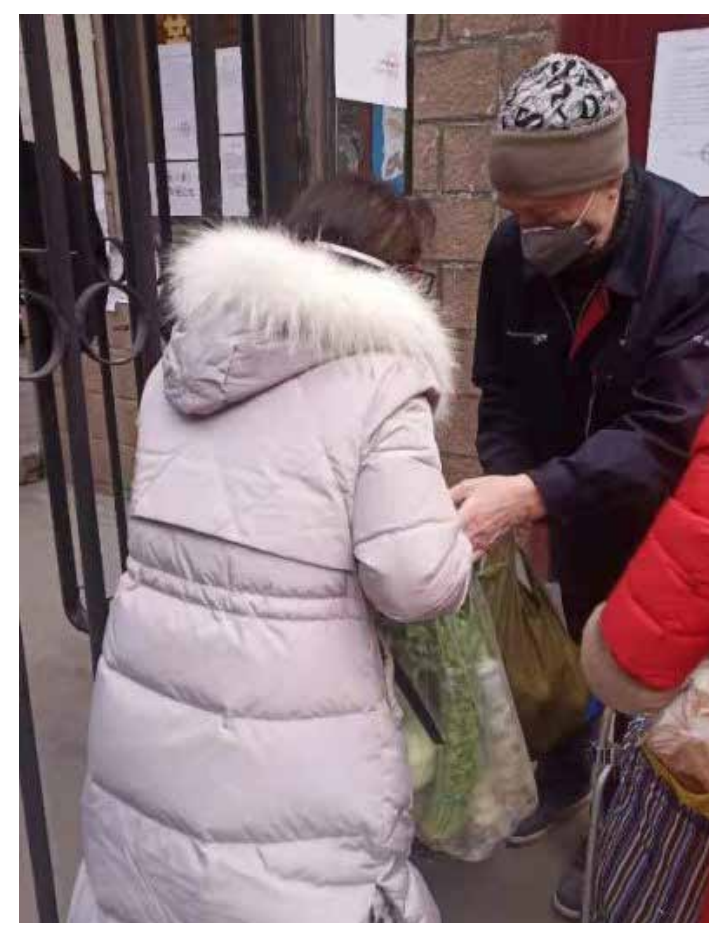

Фото 11. Профессор Павел Николаев поддерживает противоэпидемические меры города Сянфан, 27 февраля 2020 г.

26 мая 2021 года между Институтом передовых технологий Уханьской компании Чжункэ и Винницким национальным техническим университетом состоялась видеоконференция, в результате которой стороны подписали Протокол о сотрудничестве с целью строительства совместного китайско-украинского инновационного центра [武汉中科... 2021].

За 60 лет сотрудничества провинция Хубэй и её городские администрации неоднократно демонстрировали свои особенности и преимущества. Возглавляя административную деятельность, Хубэйское народное правительство обеспечивает стабильный политический климат и способствует международному сотрудничеству. Город Ухань демонстрирует свои большие амбиции и способность организовывать масштабные мероприятия. Также он предоставляет много шансов и возможностей для промышленного и научно-образовательного сотрудничества. Город Ичан выступает в качестве чистого и цивилизованного субъекта, который достиг успехов в промышленных и 
научно-технических проектах. Город Цзинчожу всегда выражал свое позитивное отношение к Украине, кроме того, он привлекает украинский народ своей древней историей и культурой. Город Шиянь демонстрирует потенциал сотрудничества в области ушу, боевых искусств и медицины. Города Сянфань и Сяньтао имеют богатый опыт сотрудничества с украинскими специалистами в сфере технических и инженерных наук.

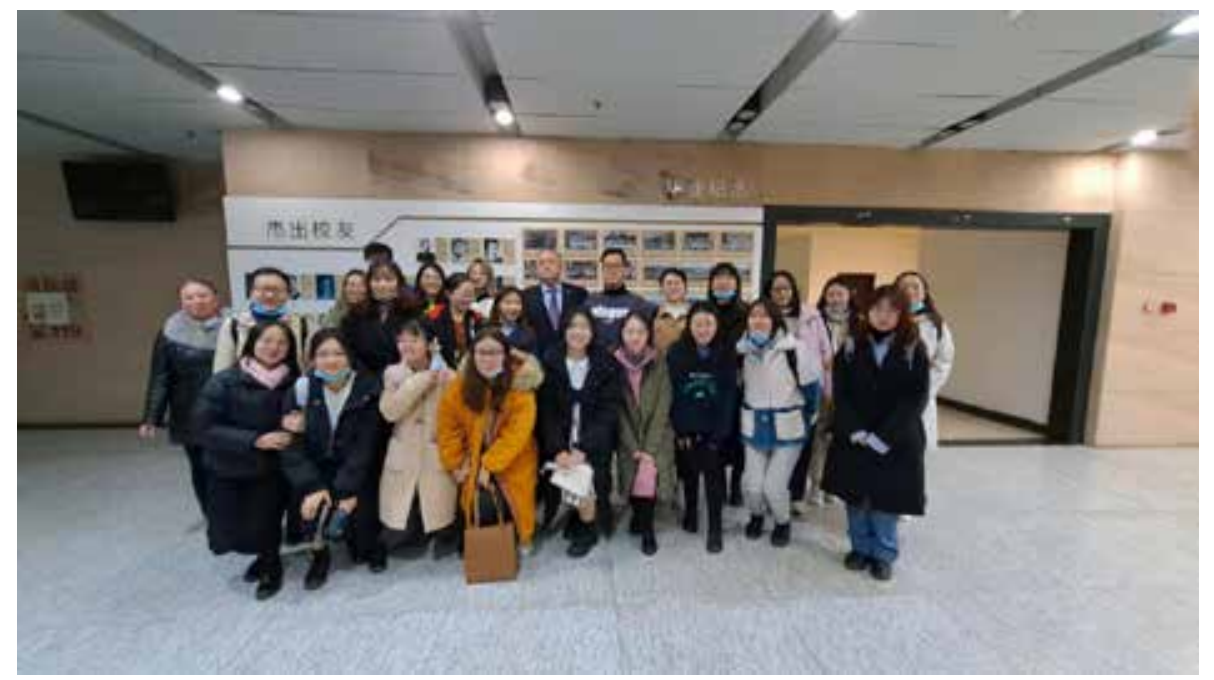

Фото 12. Посол Украины Сергей Камышев со студентами и магистрами факультета русского языка Института иностранных языков и литературы Уханьского университета, которые посещают занятия по украинскому языку

Учитывая вышеперечисленное, можно прийти к следующим выводам:

1. В XXI веке между провинцией Хубэй и областями Украины сохранились дружеские отношения, взаимопонимание и традиция обменов визитами в политической, экономическо-технической и научно-образовательной сферах.

2. Обе стороны накопили достаточно богатый опыт и заложили документальную основу для развития сотрудничества, особенно в области сельского хозяйства, машиностроения, авиатехники, инфраструктуры, сварочной промышленности и разработки новых стальных материалов. Перспективным направлением является сотрудничество в области медицины и фармацевтики, оптико-волоконного производства, лазерной техники и сетевых услуг.

3. Обе стороны добились больших успехов в обмене товарами, специалистами и студентами. Китайские и украинские мигранты также сыграли не менее важную роль в развитии экономики и образования обеих стран.

4. Сотрудничество между госучреждениями и предприятиями оставляет желать лучшего. Для реализации договоренностей нужна государственная поддержка, которую можно получить только после всестороннего и тщательного изучения партнеров. Отсюда можно увидеть перспективы научноисследовательской работы специалистов по страноведению и регионоведению. А для улучшения качества сотрудничества необходимы переводчики, которые профессионально владеют языком и знают правила межкультурной коммуникации. 
5. В связи с этим перед китайскими украиноведами и украинскими китаеведами стоит большая задача, которая заключается в содействии друг другу в создании общей платформы связей, расширении непосредственных каналов для углубления взаимопонимания, познании новейших достижений и изменений двух стран, изучении их политического, экономического, общественного и научно-образовательного состояния, совместном переводе новейших научных работ, составлении лингвистических учебников и подготовке специалистов по китаеведению и украиноведению с целью углубления взаимопонимания китайского и украинского народов.

\section{ЛИТЕРАТУРА}

Стражник Л., Иероглиф счастья, Голос Украины, available at: www.golos. com.ua/rus/article/342098 (accessed 7 December 2021).

Тянь Ю., Андреева Т.Ю. «Политический, экономический и культурный обмен между Хубэем и Украиной: 1950-1990 гг.», Китаєзнавчі дослідження. 2020. № 2. C. 39-56.

保畜禽“米袋子”，省长投集团所属湖北粮油进口五千吨饲料原料应急 （2020），湖北省人民政府国有资产监督管理委员会，available at: http://gzw. hubei.gov.cn/fbjd/gzdt/fz/202002/t20200218_2105985.shtml (accessed 30 October 2020).

蔡志文，徐章：“走出去”开拓发展新空间-湖北农垦海外农业开发的实践 与思考[j].中国农垦, 2011 № 5. 61-62.

2019茶叶国际采购商宜昌行交出沉甸甸的答卷（2019), 三峡日报, available at: http://epaper.cn3x.com.cn/sxrb/content/201905/06/c107387.html (accessed 10 October 2020).

陈辉教授率团出访乌克兰 (2017), 武汉理工大学能源与动力工程学 院, available at: http://sep.whut.edu.cn/jlhz/jldz/201805/t20180514_612774.shtml (accessed 17 October 2020).

东风汽车: 机构重仓, 底部井喷（2006），和讯, available at: http://futures. money.hexun.com/1774609.shtml (accessed 10 December 2020).

东风汽车”乌克兰厂 07年竣工主推轻型商用车（2006），中国国务院国有 资产监督委员会, available at: www.sasac.gov.cn/n2588025/n2588124/c3943290/ content.html (accessed 10 December 2020).

贡献智慧，播种友谊 - 荣获2010年国家“友谊奖”和省政府“编钟奖”的在鄂 外国专家简介（2010），湖北日报：2010年9月29日.

关于报送《湖北省政府代表团访问波兰、乌克兰、俄罗斯情况报告》的报 告（2007），湖北省人民政府外事办公室, available at: http://www.fohb.gov.cn/ details 4392.html (accessed 15 October 2020).

2017 光谷航天激光技术产业国际论坛在武汉召开（2017），湖北网台， available at: http://news.hbtv.com.cn/p/1008833.html (accessed 16 October 2020).

国际友城大会嘉宾议焦点话题：武汉要成为“一带一路”重要节点城市 （2018），大武汉. available at: http://www.app.dawuhanapp.com/p/58157.html (accessed 10 October 2020).

李银阶: 中国演员无与伦比 - 湖北省黄梅戏剧团乌克兰演出侧记. 黄梅戏 艺术. 2001 № 2.19 .

架设世界贸易桥梁，谱写湖北开放新篇：湖北贸促会改革开放40周年纪实 （2019），长江云（湖北网络广播电视台）, available at: http://news.hbtv.com. cn/p/1673692.html 20210824 (accessed 10 October 2020). 
荆州市和乌克兰白采尔科维市加深友好交流与发展（2017），荆州新闻 网, available at: www.jznews.com.cn/comnews/system/2017/06/08/011905979. shtml (accessed 10 October 2020).

湖北长阳宏信集团拟在乌克兰投资锰矿尾矿二次开发利用（2008），中华 人民共和国驻乌克兰大使馆经济商务处, available at: http://ua.mofcom.gov.cn/ aarticle/jmxw/200806/20080605593002.html (accessed 16 November 2020).

湖北端出科技成果转移转化“豪华套餐” (2021), 腾讯网, available at: https://new.qq.com/rain/a/20210629A01URU00 202107152021050 (accessed 15 October 2020).

湖北高校教师献艺“我和我的祖国”唱响乌克兰（2019），荆楚网, available at: http://news.cnhubei.com/huangshi/p/12294624.html (accessed 20 June 2020).

湖北猴王治金复合包芯线开发项目可行性研究报告（2004），原创力文 档, available at: https://max.book118.com/html/2020/0614/7013051150002141. shtm (accessed 10 October 2020).

湖北将推动这五个产业迈向万亿级（2021）, 荆楚网, available at: http:// news.cnhubei.com/content/2021-06/22/content_13876860.html (accessed 22 June 2021).

湖北年鉴：2008，武汉，湖北省地方志编纂委员会办公室.

湖北省农垦海外拓荒，走出去拓展空间（2011），湖北省人民政府， available at: www.hubei.gov.cn/hbgk/dshb/201112/t20111228_282214.shtml (accessed 15 October 2020).

湖北省友好代表团结束对格乌两国的访问（2006）, 荆楚网, available at: www.cnhubei.com/200608/ca1161058.htm (accessed 20 October 2020).

湖北省友好代表团近日访问东欧两国（2010），湖北省人民政府, available at: www.hubei.gov.cn/zwgk/hbyw/hbywqb/201112/t20111214_1470392.shtml (accessed 20 October 2020).

湖北省长会见亚洲开发银行官员和乌克兰客人（2001）, 新浪网, available at: http://news.sina.com.cn/c/204020.html (accessed 30 September 2020).

省科技代表团结束出访返汉 (2005), 荆楚网, available at: www.cnhubei. com/200510/ca916123.htm (accessed 15 October 2020).

首班武汉直达乌克兰中欧班列抵达基辅（2020），百家号， available at: https://baijiahao.baidu.com/s?id=1671525580428321989\&wfr=spider\&for $=$ pc (accessed 07 July 2020).

外语学院俄语系与乌克兰研究中心举办 “后疫情时代下的中乌教育和科技 合作的前景与路径” (2021), 武汉大学外国语言文学学院, available at: http:// fls.whu.edu.cn/info/1016/6112.htm (accessed 13. November 2021).

万里友谊一线牵，“武汉-基辅”班列首发（2020），武汉汉欧国际物流有 限公司, available at: www.wae-logistics.com/news_show.aspx?id=1077 (accessed: 20 June 2020).

我院参加“中国-乌克兰科技创新展”（2017），华中科技大学能源与动力 工程学院, available at: http://energy.hust.edu.cn/info/1098/5087.htm (accessed 04 December 2020).

乌克兰扎波罗热国立医科大学来校交流访问（2019），湖北医药学院， available at: www.hbmu.edu.cn/info/1082/12526.htm (accessed 10 October 2020).

2013 武汉国际交流活动周将于11月下旬在武汉举行（2013），凤凰 网, available at: http://hb.ifeng.com/dfzx/detail_2013_11/18/1474744_0.shtml (accessed 15 October 2020). 
武汉市代表团访问基辅波尔多（2004），搜狐新闻, available at: http://news. sohu.com/2004/06/14/72/news220517212.shtml (accessed 10 November 2020).

武汉携手20个国际友好城市筹谋《武汉2049规划》（2013），凤凰网湖 北, available at: http://hb.ifeng.com/news/cjgc/detail_2013_11/20/1483584_2. shtml (accessed 02 May 2020).

武汉夜景更美了越来越有国际范（2019），武汉市文化和旅游局, available at: http://wlj.wuhan.gov.cn/zwgk_27/zwdt/jdxw/202001/t20200107_577013.shtml (accessed 10. October 2020).

武汉中科先进技术研究院与乌克兰文尼察国立技术大学签订合作备忘录 (2021)，武汉大小事儿, available at: https://baijiahao.baidu.com/s?id=170090 $3592666866143 \& w f r=$ spider\&for $=$ pc (accessed 27 May 2020).

乌克兰博格丹集团公司开始正式生产江淮汽车 (2013), 环球网, available at: https://china.huanqiu.com/article/9CaKrnJDvgF (accessed 10 November 2020). 乌克兰友人点赞襄阳防控疫情 (2020), 网易, available at: https://3g.163. com/local/article/F6DBEBMU04089AUR.html (accessed 07 July 2021).

乌克兰华侨华人协会代表团访问湖北十堰（2016），中国新闻网湖北， available at: www.hb.chinanews.com/news/2016/1230/268950.html (accessed 10 October 2020).

乌克兰基辅州第一副州长马斯卡连卡一行访鄂（2011），湖北省人民 政府外事办公室，available at: www.fohb.gov.cn/details_13212.html (accessed 10 November 2020).

乌克兰基辅州州长普列夏日纽克一行访鄂（2011）, 湖北省人民政府外事 办公室, available at: www.fohb.gov.cn/details_14006.html (accessed 15 October 2020).

乌克兰将从中国进口1000辆客车（2006）, 央视国际，available at: http:// news.cctv.com/financial/20060722/100956.shtml (accessed 30 October 2020).

乌克兰将在我省建设高科技农业园（2003），湖北省人民政府外事办公 室, available at: www.fohb.gov.cn/details_3215.html (accessed 30 September 2020). 乌克兰教授宜昌寻“茶缘”（2016），中国新闻网湖北，available at: www. hb.chinanews.com/news/2016/0830/258701.html (accessed 10 October 2020).

乌克兰塔夫利达国立大学来校访问（2017），中国招生考试全视角网， available at: www.qsjly.cn/Item/Show.asp? $\mathrm{m}=1 \& \mathrm{~d}=48034$ (accessed 16 October 2020).

乌克兰选手在线比拼汉语翻译技能，第一名将前往武汉大学进修（2021）, 武汉大学新闻网, available at: http://news.whu.edu.cn/info/1006/64007.htm (accessed April 2021).

乌克兰扎波罗热市（2017），宜昌市人民政府外事办公室，available at: http://wsb.yichang.gov.cn/content-41252-822619-1.html (accessed 30 October 2020).

乌克兰扎波罗热州希加强同我省的合作（2004），湖北省人民政府外事 办公室, available at: www.fohb.gov.cn/details_13910.html (accessed 11 October 2020).

乌克兰驻华大使焦明访问湖北（2018），湖北省人民政府外事办公室. available at: www.fohb.gov.cn/details_14502.html (accessed 17 October 2020).

乌克兰驻华大使率团访问外语学院俄罗斯乌克兰研究中心（2018），武汉 大学外国语言文学学院. available at: https://fls.whu.edu.cn/info/1020/2364.htm (accessed 10 October 2020). 
乌克兰驻华大使谢尔盖·卡梅舍夫来校访问（2020）, 武汉大学新闻网, available at: https://news.whu.edu.cn/info/1006/62644.htm (accessed 26 November 2020).

乌克兰驻华大使谢尔盖·卡梅舍夫一行来访（2020）, 武汉大学外国语 言文学学院，available at: http://fls.whu.edu.cn/info/1016/4785.htm (accessed 27 November 2020).

新武汉史记(1949-2009): 涂文学主编 [M], 武汉, 武汉出版社, 2010.762页. 友城市长议长接受长江日报记者采访与武汉携手打造国际友城交流合作 典范（2017），武汉市人民政府外事办公室，available at: www.whswwb.org. cn/xwzx_38289/wsdt/202008/t20200814_1424386.shtml (accessed 16 October 2020).

张岱梨率湖北省政府代表团访问德国和乌克兰（2011），湖北省 人民政府，available at: www.hubei.gov.cn/zwgk/hbyw/hbywqb/201112/ t20111214_1473504.shtml (accessed 15 October 2020).

张通率团访问欧洲三国（2013），网易新闻，available at: www.163.com/ news/article/9D2C4NSU00014AED.html (accessed 15 October 2020).

章笑梅会长会见乌克兰驻华大使谢尔盖·卡梅舍夫 (2018)，中国国际贸 易促进委员会湖北省委员会, available at: http://www.hbccpit.org/main-dtxw/ cont/news-13138.html (accessed 01 September 2021).

直达乌克兰中欧班列抵达基辅（2020），人民网，available at: http://ydyl. people.com.cn/n1/2020/0708/c411837-31775489.html (accessed 08 July 2020).

2018中国湖北-乌克兰经贸洽谈会成功举办 (2018)，中国国际商会, available at: www.ccoic.cn/cms/content/9168 (accessed 12 September 2020).

2018中国湖北一乌克兰投资贸易洽谈会在基辅举行（2018），中华人 民共和国驻乌克兰大使馆经济商务处, available at: http://ua.mofcom.gov.cn/ article/c/201809/20180902789740.shtml (accessed 10 October 2020).

\section{REFERENCES}

Bao xuqin "midaizi", sheng changtou jituan suoshu hubei liangyou jinkou wuqiandun siliao yuanliao yingji (2020), Hubeisheng renmin zhengfu guoyou zichan jiandu guanli weiyuanhui, State-owned Assets Supervision and Administration Commission of Hubei Provincial People's Government website, available at: http://gzw.hubei.gov.cn/fbjd/gzdt/fz/202002/t20200218_2105985.shtml (accessed 30 October 2020) (in Chinese).

Cai Zhiwen, Xu Zhang (2011), "Zouchuqu kaituo fazhan xinkongjian - hubei nongken haiwai nongye kaifade shijian yu sikao", Zhongguo nongken, 2011. No. 5. Pp. 61-62. (in Chinese).

2019 Chaye guoji caigou yichangxing jiaochu chendiandian de dajuan (2019), Sanxia ribao, Sanxia daily website, available at: http://epaper.cn3x.com.cn/sxrb/ content/201905/06/c107387.html (accessed 10 October 2020) (in Chinese).

Chenhui jiaoshou shuaituan chufang wukelan (2017), Wuhan ligong daxue nengyuan yu dongli gongcheng xueyuan, School of Energy and Power Engineering, Wuhan University of Technology website, available at: http://sep.whut.edu.cn/jlhz/ jldz/201805/t20180514_612774.shtml (accessed 17 October 2020) (in Chinese).

Dongfeng qiche: jigou zhongcang, dibu jingpen (2006), Hexun, Hexun website, available at: http://futures.money.hexun.com/1774609.shtml (accessed 10 December 2020) (in Chinese). 
"Dongfeng qiche" wukelan chang 07 nian jungong, zhutui qingxing shangyongche (2006), Zhongguo guowuyuan guoyou zichan jiandu weiyuanhui, State-owned Assets Supervision Commission of the State Council of China, available at: www. sasac.gov.cn/n2588025/n2588124/c3943290/content.html (accessed 10 December 2020) (in Chinese).

Guanyu baosong Hubeisheng zhengfu dianbiaotuan fangwen bolan, wukelan, eluosi qingkuang baogao de baogao, Hubeisheng renmin zhengfu waishi bangongshi, Foreign Affairs Office of Hubei Provincial People's Government website, available at: http://www.fohb.gov.cn/details_4392.html (accessed 15 October 2020) (in Chinese).

Guoji youcheng dahui jiabin yi redian huati: wuhan yao chengwei "yidai yilu" zhongyao jiedian chengshi (2018), Da wuhan, Big Wuhan website, available at: www.app.dawuhanapp.com/p/58157.html (accessed 10 October 2020) (in Chinese).

Gongxian zhihui, bozhong youyi - ronghuo 2010 nian guojia "youyijiang" he shengzhengfu "bianzhongjiang" de zaie waiguo zhuanjia jianjie (2010), Hubei ribao (2010), 29 September 2010. (in Chinese).

2017 Guanggu hangtian jiguang jishu chanye guoji luntan zai wuhan zhaokai (2017), Hubei wangtai, Hubei provise Net station website, available at: http://news. hbtv.com.cn/p/1008833.html (accessed 16 October 2020) (in Chinese).

Hubei changyang hongxin jituan ni zai wukelan touzi mengkuang weikuang erci kaifa liyong (2008), Zhonghua renmin gongheguo zhu wukelan dashiguan jingji shangwuchu, Economic and Commercial Office of the Embassy of the People's Republic of China in Ukraine website, available at: http://ua.mofcom.gov.cn/aarticle/ jmxw/200806/20080605593002.html (accessed 16 November 2020) (in Chinese).

Hubei duanchu keji chengguo zhuanyi zhuanhua "haohua taocan" (2021), Tengxun wang, Tencent website, available at: https://new.qq.com/rain/ a/20210629A01URU00\%2020210715\%202021050 (accessed 15 October 2020) (in Chinese).

Hubei gaoxiao jiaoshi xianyi "wo he wode zuguo" changxiang wukelan (2019), Jingchuwang, Jingchu website, available at: http://news.cnhubei.com/ huangshi/p/12294624.html (accessed 20 June 2020) (in Chinese).

Hubei houwang yejin fuhe baoxinxian kaifa xiangmu kexingxing yanjiu baogao (2004), Yuanchuangli wendang, Original force document website, available at: https://max.book118.com/html/2020/0614/7013051150002141.shtm (accessed 10 October 2021) (in Chinese).

Hubei jiang tuidong zhewuge chanye maixiang wanyiji (2021), jingchuwang, Jingchu website, available at: http://news.cnhubei.com/content/2021-06/22/ content_13876860.html (accessed 22 June 2021) (in Chinese).

Hubei nianjian (2008), hubeisheng difangzhi bianzuan weiyuanhui bangongshi, 2009. (in Chinese).

Hubeisheng nongken haiwai tuohuang, zouchuqu tuozhan kongjian (2011), hubeisheng renmin zhengfu, People's Government of Hubei Province website, available at: www.hubei.gov.cn/hbgk/dshb/201112/t20111228_282214.shtml (accessed 15 October 2020) (in Chinese).

Hubeisheng youhao daibiaotuan jieshu dui gewu liangguo de fangwen (2006), Jingchuwang, Jingchu website, available at: www.cnhubei.com/200608/ca1161058. htm (accessed 20 October 2020) (in Chinese). 
Hubeisheng youhao daibiaotuan jinri fangwen dongou liangguo (2010), hubeisheng renmin zhengfu, People's Government of Hubei Province website, available at: www.hubei.gov.cn/zwgk/hbyw/hbywqb/201112/t20111214_1470392. shtml (accessed 20 October 2020) (in Chinese).

Hubei shengzhang huijian yazhou kaifa yinhang guanyuan he wukelan keren (2001), Xinlang wang, Xinlang website, available at: http://news.sina.com. $\mathrm{cn} / \mathrm{c} / 204020 . \mathrm{html}$ (accessed 30 September 2020) (in Chinese).

Jiashe shijie maoyi qiaoliang, puxie hubei kaifang xinpian: hubei maocuhui gaige kaifang 40 zhounian jishi (2019), Changjiang yun (Hubei wangluo guangbo dianshitai), Changjiang Cloud (Hubei Internet Radio and Television Station) website, available at: http://news.hbtv.com.cn/p/1673692.html 20210824 (accessed 10 October 2020) (in Chinese).

Jingzhoushi he wukelan baicaierkeweishi jiashen youhao jiaoliu yu fazhan (2017), Jingzhou xinwen wang, Jinbzhou's News network website, available at: www.jznews.com.cn/comnews/system/2017/06/08/011905979.shtml (accessed 10 October 2020) (in Chinese).

Li Yinjie (2001), "Zhongguo yanyuan wuyulunbi - hubeisheng huangmei xijutuan wukelan yanchu ceji”, Huangmeixi yishu, 2001. No. 2. P. 19. (in Chinese).

Luoqingquan shuai hubei zhengfu daibiaotuan fangwen bolan wukelan he eluosi (2007), Zhonghua renmin gongheguo zhongyang renmin zhengfu, Central People's Government of the People's Republic of China website, available at: www.gov. cn/govweb/gzdt/2007-08/24/content_726243.htm (accessed 10 November 2020) (in Chinese).

Sheng keji daibiaotuan chufang fanhan (2005), Jingchu website, available at: www.cnhubei.com/200510/ca916123.htm (accessed 15 October 2020) (in Chinese).

Shouban wuhan zhida wukelan zhongou banlie dida jifu (2020), Baijia hao, Baijiahao website, available at: https://baijiahao.baidu.com/s?id=16715255804283 21989\&wfr=spider\&for=pc (accessed 7 July 2020) (in Chinese).

Straznik L. (2021), Ieroglif schastya, Golos Ukraine, Voice of Ukraine website, available at: www.golos.com.ua/rus/article/342098 (accessed 7 December 2021) (in Russian).

Tian Y. and Adreieva T.U. (2020), "Politicheski, ekonomicheski i kulturniy obmen mezdu Hubeiem i Ukrainoy: 1950-1990", Kytayeznavchi doslidzhennya, 2020 No. 2. C. 39-56. (in Russian).

Waiyu xueyuan eyuxi yu wukelan yanjiu zhongxin juban "houyinqingshidaixia de zhongwu jiaoyu he keji hezuo de qiangjing yu lujing (2021), School of Foreign Languages and Literature, Wuhan University website, available at: http://fls.whu. edu.cn/info/1016/6112.htm (accessed 13 November 2021) (in Chinese).

Wanli youyi yixian qian, "wuhan-jifu” banlie shoufa (2020), Wuhan han'ou guoji wuliu youxian gongsi, Wuhan Han'ou International Logistics Co., Ltd. website available at: www.wae-logistics.com/news_show.aspx?id=1077 (accessed 20 June 2020) (in Chinese).

Woyuan canjia "zhongguo-wukelan keji chuangxinzhan" (2017), Huazhong keji daxue nengyuan yu dognli gongcheng xueyuan, School of Energy and Power Engineering, Huazhong University of Science and Technology website, available at: http://energy.hust.edu.cn/info/1098/5087.htm (accessed 04 December 2020) (in Chinese). 
2013 Wuhan guoji jiaoliu huodongzhou jiangyu 11yue xiaxun zai wuhan juxing (2013), Fenghuang wang, Fenghuang website: available at: http://hb.ifeng.com/ dfzx/detail_2013_11/18/1474744_0.shtml (accessed 15 October 2020) (in Chinese).

Wuhanshi daibiaotuan fagwen jifu boerduo (2004), Souhu xinwen, Souhu New's net, available at:http://news.sohu.com/2004/06/14/72/news220517212.shtml (accessed 10 November 2020) (in Chinese).

Wuhan xieshou 20 ge guoji youhao chengshi choumou wuhan 2049 guihua (2013), fenghuangwang hubei, Fenghuang website in provice Wubei, available at: http://hb.ifeng.com/news/cjgc/detail_2013_11/20/1483584_2.shtml (accessed 02 May 2020) (in Chinese).

Wuhan yejing gengmeile yuelai yueyou guojifan (2019), Wuhanshi wenhua he lvyou ju, Wuhan Municipal Bureau of Culture and Tourism website, available at: http://wlj.wuhan.gov.cn/zwgk_27/zwdt/jdxw/202001/t20200107_577013.shtml (accessed 10 October 2020) (in Chinese).

Wuhan zhongke xianjin jishu yanjiuyuan yu wukelan wennicha guolijishu daxue qianding hezuo beiwanglu (2021), Wuhandaxiaoshier, Wuhan's big and small things website, available at: https://baijiahao.baidu.com/s?id=1700903592666866143\&wf $\mathrm{r}=$ spider\&for $=\mathrm{pc}$ (accessed 27 May 2021) (in Chinese).

Wukelan bogedan jituan gongsi kaishi zhengshi shengchan jianghuai qiche (2013), Huanqiu wang, Huanqiu website, available at: https://china.huanqiu.com/ article/9CaKrnJDvgF (accessed 10 November 2020) (in Chinese).

Wukelan huaqiao huaren xiehui daibiaotuan fangwen hubei shiyan (2016), Zhongguo xinwenwang hubei, China News Network Wubei website, available at: www.hb.chinanews.com/news/2016/1230/268950.html (accessed 10 October 2020) (in Chinese).

Wukelan jifuzhou diyi fuzhouzhang masikalianka yixing fang e (2011), hubeisheng renmin zhengfu bangongshi, Foreign Affairs Office of Hubei Provincial People's Government website, available at: www.fohb.gov.cn/details_13212.html (accessed 10 November 2020) (in Chinese).

Wukelan jifuzhou zhouzhang puliexiariniuke yixing fang e (2011), hubeisheng renmin zhengfu bangongshi, Foreign Affairs Office of Hubei Provincial People's Government website, available at: www.fohb.gov.cn/details_14006.html (accessed 15 October 2020) (in Chinese).

Wukelan jiangcong zhongguo jinkou 1000 liang keche (2006), Yangshi guoji, CCTV International website, available at: http://news.cctv.com/ financial/20060722/100956.shtml (accessed 30 October 2020) (in Chinese).

Wukelan jiangzai wosheng jianshe gaokeji nongyeyuan (2003), Hubeisheng renmin zhengfu waishi bangongshi, Foreign Affairs Office of Hubei Provincial People's Government website, available at: www.fohb.gov.cn/details_3215.html (accessed 30 September 2020) (in Chinese).

Wukelan jiaoshou yichang xun "chayuan" (2016), Zhongguo xinwenwang hubei, China News Network Wubei website, available at: www.hb.chinanews.com/ news/2016/0830/258701.html (accessed 10 October 2020) (in Chinese).

Wukelan tafu lida guoli daxue laixiao fangwen (2017), Zhongguo zhaosheng kaoshi quanshijiao wang, China Admissions Examination Full Perspective Network, available at: www.qsjly.cn/Item/Show.asp?m=1\&d=48034 (accessed 16 October 2020) (in Chinese). 
Wukelan xuanshou zaixian bipin fanyi jineng, diyiming jiang qianwang wuhan daxue jinxiu (2021), Wuhan daxue xinwenwang, Wuhan University New's net, available at: http://news.whu.edu.cn/info/1006/64007.htm (accessed 13 April 2021) (in Chinese).

Wukelan youren dianzan xiangyang fangkong yiqing (2020), Wangyi, NetEase website, available at: https://3g.163.com/local/article/F6DBEBMU04089AUR. html (accessed 7 July 2020). (in Chinese).

Wukelan zhaboluore guoli yike daxue laixiao jiaoliu fangwen (2019), Hubei yiyao xueyuan, Hubei Academy of Medicine website, available at: www.hbmu.edu. cn/info/1082/12526.htm (accessed 10 October 2020) (in Chinese).

Wukelan zhaboluoreshi (2017), Yichangshi renmin zhengfu waishi bangongshi, Foreign Affairs Office of Yichang Municipal People's Government website, available at: http://wsb.yichang.gov.cn/content-41252-822619-1.html (accessed 30 October 2020) (in Chinese).

Wukelan zhaboluorezhou xi jiaqiang tong wosheng de hezuo (2004), Hubeisheng renminzhengfu waishi bangongshi, Foreign Affairs Office of Hubei Provincial People's Government website, available at: www.fohb.gov.cn/details_13910.html (accessed 11 October 2020) (in Chinese).

Wukelan zhuhua dashi jiaoming fangwen hubei (2018), Hubeishengrenmin zhengfu waishi bangongshi, Foreign Affairs Office of Hubei Provincial People's Government website, available at: www.fohb.gov.cn/details_14502.html (accessed 17 October 2020) (in Chinese).

Wukelan zhuhua dashi shuaituan fangwen waiyu xueyuan eluosi wukelan yanjiu zhongxin (2018), Wuhan daxue waiguo yuyan wenxue xueyuan, School of Foreign Languages and Literature of Wuhan University website, available at: https://fls.whu. edu.cn/info/1020/2364.htm (accessed 10 October 2020) (in Chinese).

Wukelan zhuhua dashi xieergai kameishefu laixiao fangwen (2020), wuhandaxue xinwen wang, Wuhan University New's net, available at: https://news.whu.edu.cn/ info/1006/62644.htm (accessed 26 November 2020) (in Chinese).

Wukelan zhuhua dashi xieergai kameishefu yixing laifang (2020), Wuhan daxue waiguo yuyan wenxue xueyuan, School of Foreign Languages and Literature of Wuhan University website, available at: http://fls.whu.edu.cn/info/1016/4785.htm (accessed 27 November 2020) (in Chinese).

Xin wuhan shiji (1949-2009), Tu Wenxue zhubian, Wuhan press, Wuhan, 2010. (in Chinese).

Youcheng shizhang yizhang jieshou changjiang ribao jizhe caifang, yu wuhan xieshou dazao guoji youcheng jiaoliu hezuo dianfan (2017), Wuahanshi renmin zhengfu waishi bangongshi, Foreign Affairs Office of Wuhan Municipal People's Government website, available at: www.whswwb.org.cn/xwzx_38289/wsdt/202008/ t20200814_1424386.shtml (accessed 16 October 2020) (in Chinese).

Zhangdaili shuai hubeisheng zhengfu daibiaotuan fangwen deguo hewukelan (2011), Hubeisheng renmin zhengfu, People's Government ofHubei Province website, available at: www.hubei.gov.cn/zwgk/hbyw/hbywqb/201112/t20111214_1473504. shtml (accessed 15 October 2020) (in Chinese).

Zhangtong shuaituan fangwen ouzhou sanguo (2013), Wangyi xinwen, Wangyi New's net, available at: www.163.com/news/article/9D2C4NSU00014AED.html (accessed 15 October 2020) (in Chinese). 
Zhangxiaomei huizhang huijian wukelan zhuhua dashi xieergai kameishefu (2018), Zhongguo guoji maoyi cujin weiyuanhui hubeisheng weiyuanhui, Hubei Provincial Committee of China Council for the Promotion of International Trade, available at: http://www.hbccpit.org/main-dtxw/cont/news-13138.html (accessed 01 September2021) (in Chinese).

Zhida wukelan zhong'ou banlie dida jifu (2020), Renmin wang, People website, available at: http://ydyl.people.com.cn/n1/2020/0708/c411837-31775489.html (accessed 08 July 2020) (in Chinese).

2018 Zhongguo hubei - wukelan jingmao qiatanhui chenggong juban (2018), Zhongguo guoji shanghui, China Chamber of International Commerce website, available at: www.ccoic.cn/cms/content/9168 (accessed 12 September 2020) (in Chinese).

2018 Zhongguo hubei - wukelan touzi maoyi qiatanhui zai jifu juxing (2018), Zhonghua renmin gongheguo zhu wukelan dashiguan jingji shangwuchu, Economic and Commercial Office of the Embassy of the People's Republic of China in Ukraine website, available at: http://ua.mofcom.gov.cn/article/c/201809/20180902789740. shtml (accessed 10 October 2020) (in Chinese).

Стаття надійшла до редакиії 11.12.2021 